tion of the molecular weight in the presence of sodium dodecyl sulfate, ${ }^{97}$ it appears that this enzyme is composed of two identical subunits with a molecular weight of approximately 50000.

The purified acid phosphatase was active toward $p$-nitrophenyl phosphate (relative activity (R.A): 100), $\alpha$-glycerophosphate (R.A: 55 ), $\beta$-glycerophosphate (R.A: 67 ), pyridoxal phosphate (R.A: 41), fructose 6-phosphate (R.A: 28), fructose 1,6-diphosphate (R.A: 34), glucose 6-phosphate (R.A: 36), 2'-AMP (R.A: 25), 3'-AMP (R.A: 70), 5'-AMP (R.A: 14), ADP (R.A: 55), ATP (R.A: 55), NADP+ (R.A: 51), and inorganic pyrophosphate (R.A: 98). No phosphodiesterase activity was detected toward $\mathrm{NAD}^{+}$and diphenyl phosphate. The enzyme had $\mathrm{pH}$ optimum around $\mathrm{pH} 5.5$ with the $K_{\mathrm{m}}$ value of $3.9 \times 10^{-4} \mathrm{M}$ for $p$-nitrophenyl phosphate.

Acknowledgements Thanks are due to Prof. K. Uehara, Osaka University, for his encouragement. The authors express their thanks to Mr. Y. Sakamoto of the Faculty of Medicine, Osaka University for carrying out the ultracentrifugal analysis. They are also indebted to Nissei Sangyo Co., Ltd. for metal analysis. They wish to thank Mr. H. Nakamura and Mr. M. Nishihashi for the technical assistance in preparing the enzyme. This work was supported in part by a grant from the Ministry of Education, Science and Culture of Japan.

9) K. Weber and M. Osborn, J. Biol. Chem., 244, 4406 (1969).

Studies on Quinones and Related Compounds in Higher Plants. V.1) Model Experiments for the Preparation of Tritium-labeled Precursors for the Biosynthetic Studies of Prenylnaphthoquinone Congeners ${ }^{2)}$

\author{
Kenichiro Inoue, Yoshinori Shiobara, and Hiroyuki Inouye \\ Faculty of Pharmaceutical Sciences, Kyoto University ${ }^{3)}$
}

(Received September 29, 1976)

\begin{abstract}
Methods for the preparation of $\left[3^{\prime}-{ }^{2} \mathrm{H}\right]-4-\left(2^{\prime}\right.$-carboxyphenyl $)-4$-oxobutanoic acid and $\left[4,8-{ }^{2} \mathrm{H}_{2}\right]-2$-carboxy-4-hydroxy- $\alpha$-tetralone (CHT) starting from 3-methoxyphthalic anhydride have been demonstrated as model experiments for the preparation of several ${ }^{3} \mathrm{H}$-labeled compounds necessary for the elucidation of the biosynthetic pathways of prenylnaphthoquinone congeners occurring in Catalpa ovata.
\end{abstract}

Keywords_—prenylnaphthoquinones; biosynthesis; precursors; 4-(2'-carboxyphenyl)-4-oxobutanoic acid; 2-carboxy-4-hydroxy- $\alpha$-tetralone; labeling methods

Recently we reported studies on the biosynthesis of prenylnaphthoquinone congeners of Catalpa ovata G. Don such as catalpalactone (1), catalponol (2) and 4,9-dihydroxy- $\alpha$-lapachone (3) which are biosynthesized via 4-(2'-carboxyphenyl)-4-oxobutanoic acid (4). ${ }^{1,4,5)}$ As part of continuing efforts to clarify the mechanism of prenylation on their biosynthetic

1) Part IV.: H. Inouye, S. Ueda, K. Inoue, T. Hayashi, and T. Hibi, Chem. Pharm. Bull. (Tokyo), 23, 2523 (1975).

2) Part of the results reported here has been communicated in a preliminary form; Tetrahedron Letters, 1976, 1795.

3) Location: Yoshida-shimoadachi-cho, Sakyo-ku, Kyoto.

4) H. Inouye, S. Ueda, K. Inoue, T. Hayashi, and T. Hibi, Tetrahedron Letters, 1975, 2395.

5) S. Ueda, K. Inoue, T. Hayashi, and H. Inouye, Tetrahedron Letters, 1975, 2399. 
pathway, the synthesis of labeled 2carboxy-4-hydroxy- $\alpha$-tetralone (CHT) and 2-carboxy-4-oxo- $\alpha$-tetralone (COT) were required. This paper describes model experiments including deuterium labeling to establish methods for the preparation of keto diacid (4), CHT and its derivatives labeled with tritium, respectively.

We first attempted to prepare $4-\left(2^{\prime}\right.$ carboxyphenyl)-4-oxobutanoic acid (4) la-<smiles>CC1(C)CC=C(C2OC(=O)c3ccccc32)C(=O)O1</smiles>

1<smiles>CC(C)=CCC1CC(O)c2ccccc2C1=O</smiles>

2<smiles>CC1(C)CC2=C(C(=O)c3cccc(O)c3C2=O)C(O)C1</smiles>

3 beled at an aromatic position. The synthetic plan included the preparation of 4 bearing a phenolic hydroxy group and the subsequent hydrogenolysis of its phenyltetrazolyl ether to introduce the isotope into an aromatic position. ${ }^{6}$

Fusion of 3-methoxyphthalic anhydride $(5)^{7}$ with succinic acid gave two methoxy-

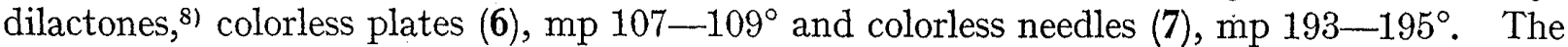
dilactone (6) was then subjected to alkali hydrolysis followed by esterification with diazomethane yielding a dimethyl ester, which was demethylated with boron tribromide to give a phenol. After treatment of this substance with 50\% sulfuric acid, the reaction product was immediately treated with diazomethane to give the succinyl group-eliminated product, methyl $m$-hydroxybenzoate (8). On the other hand, the same work up of the dilactone (7) yielded a decarboxylation product, methyl 4-(3'-hydroxyphenyl)-4-oxobutyrate (9). Accordingly, it was concluded that the dilactones (6) and (7) are the 4-methoxy- and 7-methoxy compounds, respectively, and that 8 arises from 6 via the $6^{\prime}$-methoxy (10) and $6^{\prime}$-hydroxy compounds (11), while 9 arises from 7 via the $3^{\prime}$-methoxy (12) and $3^{\prime}$-hydroxy compounds (13).

Next, methyl 4-(2'-carbomethoxy-3'-hydroxyphenyl)-4-oxobutyrate (13) was treated with 1-phenyl-5-tetrazolyl chloride in acetone in the presence of anhydrous potassium carbonate to give tetrazolyl ether (14). Catalytic hydrogenation of 14 over $10 \% \mathrm{Pd}-\mathrm{C}$ gave phthalide (15), which was formed by the hydrogenolysis of the tetrazolyloxy group accompanied by reduction of the C-4 carbonyl group, together with a further reduced compound (16). A solution of 15 in carbon tetrachloride was treated with $\mathrm{N}$-bromosuccinimide under ultraviolet (UV) irradiation to give a bromide, which was hydrolyzed with $1 \mathrm{~N} \mathrm{HCl}$ followed by esterification with diazomethane to give methyl 4-(2'-carbomethoxyphenyl)-4-oxobutyrate (17).

The tetrazolyl ether (14) was then deuterated over $10 \% \mathrm{Pd}-\mathrm{C}$ to give $\left[3,7-{ }^{2} \mathrm{H}_{2}\right]$-phthalide $\left(15-\mathrm{d}_{2}\right)$ and methyl $\left[3^{\prime}, 4,4-{ }^{2} \mathrm{H}_{3}\right]-4-\left(2^{\prime}\right.$-carbomethoxyphenyl)-butyrate $\left(16-\mathrm{d}_{3}\right)$. In the nuclear magnetic resonance (NMR) spectrum of $15-\mathrm{d}_{2}$, most of proton signals on $\mathrm{C}-3$ (dd, $\delta 5.58$ ) and C-7 (m, $\delta 7.81-8.01)$ of 15 disappeared. Bromination of $15-\mathrm{d}_{2}$ with N-bromosuccinimide followed by hydrolysis with $1 \mathrm{~N} \mathrm{HCl}$ and esterification of the product in the same way as in the case of 15 provided methyl $\left[3^{\prime}-{ }^{2} \mathrm{H}\right]-4-\left(2^{\prime}\right.$-carbomethoxyphenyl $)$-4-oxobutyrate $\left(17-\mathrm{d}_{1}\right)$. Also in the NMR spectrum of this product, most of the signals assignable to the $\mathrm{C}-3^{\prime}$ proton disappeared. As we have already reported the mild hydrolysis of 17 to give $4,{ }^{1 \text { ) }}$ it may be safely concluded that the method to label $\mathrm{C}-3^{\prime}$ position of 4 with tritium has been established.

Subsequently, CHT and its derivatives have been prepared starting from keto diester (17). This synthetic route would almost parallel the biosynthetic pathway. However, as the direct Dieckmann condensation of $\mathbf{1 7}$ gave the indandione compound (18), ${ }^{\text {9) }}$ the phthalide

6) W.J. Musliner and J.W. Gates Jr., "Organic Synthesis," 51, ed. by R.E. Benson, John Wiley, and Sons, Inc., New York, 1971, p. 82.

7) W.H. Bentley, R. Robinson, and C. Weizmann, J. Chem. Soc., 91, 109 (1907).

8) W. Roser, Ber., 17, 2770 (1884).

9) S. Eskola and E. Suomalainen, Suomen Kemistilehti, 17B, 15 (1944). 
<smiles>[R]OC(=O)CCC(=O)c1c([R2])ccc([R])c1C(=O)O[R]</smiles>

4: $\mathrm{R}=\mathrm{R}^{\prime}=\mathrm{R}^{\prime \prime}=\mathrm{H}$

$10: \mathrm{R}=\mathrm{CH}_{3}, \mathrm{R}^{\prime}=\mathrm{H}, \mathrm{R}^{\prime \prime}=\mathrm{OCH}_{3}$

11: $\mathrm{R}=\mathrm{CH}_{3}, \mathrm{R}^{\prime}=\mathrm{H}, \mathrm{R}^{\prime \prime}=\mathrm{OH}$

12: $\mathrm{R}=\mathrm{CH}_{3}, \mathrm{R}^{\prime}=\mathrm{OCH}_{3}, \mathrm{R}^{\prime \prime}=\mathrm{H}$

$13: \mathrm{R}=\mathrm{CH}_{3}, \mathrm{R}^{\prime}=\mathrm{OH}, \mathrm{R}^{\prime \prime}=\mathrm{H}$

14<smiles>COc1cccc2oc(=O)oc12</smiles>

5
$\mathrm{R}=\mathrm{H} \quad \mathrm{N}-\mathrm{N}$

$17: \mathrm{R}=\mathrm{CH}_{3}, \mathrm{R}^{\prime}=\mathrm{R}^{\prime \prime}=\mathrm{H}$<smiles>[R]c1ccc2c(c1)C1(COC(=O)C1)OC2=O</smiles>

$6: \mathrm{R}=\mathrm{OCH}_{3}, \mathrm{R}^{\prime}=\mathrm{H}$

$7: \mathrm{R}=\mathrm{H}, \mathrm{R}^{\prime}=\mathrm{OCH}_{3}$<smiles>COC(=O)CCC(=O)c1cccc(O)c1</smiles>

9<smiles>[R]OC(=O)C1CC([R])c2ccccc2C1=O</smiles>

$\mathrm{CHT}: \mathrm{R}=\mathrm{H}, \mathrm{R}^{\prime}=\mathrm{OH}, \mathrm{H}$ $\mathrm{COT}: \mathrm{R}=\mathrm{H}, \mathrm{R}^{\prime}=\mathrm{O}$

19: $\mathrm{R}=\mathrm{CH}_{3}, \mathrm{R}^{\prime}=\mathrm{OH}, \mathrm{H}$

22: $\mathrm{R}=\mathrm{CH}_{3}, \mathrm{R}^{\prime}=\mathrm{O}$<smiles>O=C1CCC(O)c2ccccc21</smiles>

21<smiles>[R]OC(=O)C1(O)CC(=O)c2ccccc2C1=O</smiles>

$23: \mathrm{R}=\mathrm{CH}_{3}$ $26: \mathrm{R}=\mathrm{H}$<smiles>O=C1C=C(O)C(=O)c2ccccc21</smiles>

24<smiles>COC(=O)c1cccc(O)c1</smiles>

8<smiles></smiles>

15<smiles>COC(=O)c1ccc2ccccc2c1O</smiles>

20<smiles>O=C(O)C(=O)CC(=O)c1ccccc1C(=O)O</smiles>

25

$\mathrm{Ph}=$ phenyl

Fig: 2

(15) in which the ketone group of $\mathbf{1 7}$ has been reduced to the hydroxy group was used as a starting material to obtain a six-membered condensation product. Substance (15) was also obtainable by reduction of $\mathbf{1 7}$ with sodium borohydride. Dieckmann condensation of $\mathbf{1 5}$ in the presence of potassium $t$-butoxide in hot toluene produced the desired 2-carbomethoxy4-hydroxy- $\alpha$-tetralone (19) in $67 \%$ yield together with small amounts of methyl 1-hydroxy2-naphthoate (20) and 4-hydroxy- $\alpha$-tetralone (21). CHT methyl ester (19) in chloroform mostly assumes the enol form as exhibited by the NMR (in $\delta \mathrm{CDCl}_{3}, 2.80$ (d, $J=6.0 \mathrm{~Hz}, \mathrm{C}-3$ methylene) and $\delta 4.80$ ( $\mathrm{t}, J=6.0 \mathrm{~Hz}, \mathrm{C}-4$ methine)) and the infrared (IR) (in $\mathrm{CHCl}_{3}, 1640$ (strong, $\mathrm{COOCH}_{3}$ of the enol form) and $1730 \mathrm{~cm}^{-1}$ (weak, $\mathrm{COOCH}_{3}$ of the keto form)). CHT methyl ester (19) was hydrolyzed with dil. $\mathrm{NaOH}$ at room temperature to give CHT, which was also found to assume the enol form on the basis of the NMR spectrum in acetone- $d_{6}$. This substance was so labile that even the crystalline form gradually underwent decarboxylation on standing at room temperature to yield 4-hydroxy- $\alpha$-tetralone (21) which is also obtainable as a minor product on Dieckmann condensation of 15. Immediately after the hydrolysis of CHT methyl ester (19), the prompt treatment of the resultant CHT with diazomethane regenerated the methyl ester (19). 
All attempts to convert CHT methyl ester (19) to COT methyl ester (22) with various oxidizing agents were unsuccessful. But oxidation of 19 with manganese dioxide gave 2carbomethoxy-2-hydroxy-4-oxo- $\alpha$-tetralone (23). Treatment of 23 with dil. $\mathrm{NaOH}$ gave lawsone (24). Although Campbell, et al. ${ }^{10)}$ assumed keto acid (25) as a biogenetic intermediate of lawsone (24), the free carboxylic acid (26) corresponding to 23 seems to be a more probable precursor of 24 than 25 . The possibility should be examined in the near future.

So far we have demonstrated the synthetic methods and chemical properties of CHT and related compounds. We next carried out the reduction of keto diester (17) with sodium borodeuteride yielding $\left[3-{ }^{2} \mathrm{H}\right]$-phthalide $\left(15-\mathrm{d}_{1}\right)$ which was then subjected to the Dieckmann condensation as described above to give $\left[4{ }^{2} \mathrm{H}\right]-\mathrm{CHT}$ methyl ester $\left(\mathbf{1 9}-\mathrm{d}_{\mathbf{1}}\right)$. Comparison of the NMR spectra of both substances revealed that the C-3 proton of $\mathbf{1 5}-\mathrm{d}_{\mathbf{1}}$ was completely replaced by deuterium, while in the Dieckmann condensation product $\left(19-d_{1}\right), 40 \%$ of the deuterium on $\mathrm{C}-4$ was retained. Hydrolysis of $19-\mathrm{d}_{\mathbf{1}}$ with dil. $\mathrm{NaOH}$ gave $\left[4^{-2} \mathrm{H}\right]-\mathrm{CHT}$ (CHT$d_{1}$ ), the NMR spectrum of which indicated that most of the deuterium of $19-d_{1}$ was retained in this compound. Accordingly, it has been demonstrated that $\left[4,8-{ }^{3} \mathrm{H}_{2}\right]-\mathrm{CHT}$ methyl ester $\left(19-t_{2}\right)$ and $\left[4,8-{ }^{3} \mathrm{H}_{2}\right]-\mathrm{CHT}\left(\mathrm{CHT}-\mathrm{t}_{2}\right)$ are obtainable by the synthesis starting with $\left[3,7-{ }^{3} \mathrm{H}_{2}\right]-$ phthalide $\left(\mathbf{1 5}-\mathrm{t}_{2}\right)$ which can be derived through the hydrogenolysis of $\mathbf{1 4}$ under tritium gas. Details of the synthesis of these tritium-labeled compounds and their administration to Catalpa ovata will be reported elsewhere.

\section{Experimental ${ }^{11)}$}

Preparation of Methoxy-dilactones (6) and (7) from 3-Methoxyphthalic Anhydride (5)-3-Methoxyphthalic anhydride (5) $(3.0 \mathrm{~g})$, succinic acid $(3.5 \mathrm{~g})$ and anhyd. AcONa $(1.5 \mathrm{~g})$ were mixed well and heated at $230^{\circ}$ for $14 \mathrm{~min}$. After cooling to room temperature, the resulting solid mass was broken up and taken into $\mathrm{CHCl}_{3}(40 \mathrm{ml})$ and $\mathrm{H}_{2} \mathrm{O}(30 \mathrm{ml})$. After removal of the insoluble material by filtration, the aqueous layer was further extracted with $\mathrm{CHCl}_{3}(2 \times 20 \mathrm{ml})$. The combined $\mathrm{CHCl}_{3}$ extracts were washed successively with sat. aq. $\mathrm{NaHCO}_{3}$ and sat. aq. $\mathrm{NaCl}$, dried over anhyd. $\mathrm{MgSO}_{4}$ and evaporated in vacuo. The crystalline residue $(1.82 \mathrm{~g})$ was purified by chromatography on silica gel with $\mathrm{C}_{6} \mathrm{H}_{6}$ and $\mathrm{C}_{6} \mathrm{H}_{6}$-ether as eluent. The first eluted compound was recrystallized from EtOH to give $6(391 \mathrm{mg})$ as colorless prisms, $\mathrm{mp} 107-109^{\circ}$. IR $v_{\max }^{\text {Nujol }} \mathrm{cm}^{-1}: 1790,1618,762,725 ; \mathrm{NMR}\left(\mathrm{CDCl}_{3}\right) \delta: 2.40-3.25\left(\mathrm{~m},-\mathrm{CH}_{2} \mathrm{CH}_{2}-\right), 3.95\left(\mathrm{~s}, \mathrm{OCH}_{3}\right), 7.21$ (dd, $J=7.0$ and $2.0 \mathrm{~Hz}, 5-\mathrm{H}$ ), 7.45 (dd, $J=7.0$ and $2.0 \mathrm{~Hz}, 7-\mathrm{H}), 7.65$ ( $\mathrm{t}, J=7.0 \mathrm{~Hz}, 6-\mathrm{H})$. Anal. Calcd. for $\mathrm{C}_{12} \mathrm{H}_{10} \mathrm{O}_{5}: \mathrm{C}, 61.54 ; \mathrm{H}, 4.30$. Found: $\mathrm{C}, 61.29 ; \mathrm{H}, 4.10$. The second eluted compound was recrystallized from MeOH to give $7(389 \mathrm{mg})$ as colorless needles, mp 193-195 ${ }^{\circ}$. IR $\nu_{\max }^{\text {Nujol }} \mathrm{cm}^{-1}: 1790,1772,1607,800$, 699; NMR $\left(\mathrm{CDCl}_{3}\right) \delta: 2.45-3.20\left(\mathrm{~m},-\mathrm{CH}_{2} \mathrm{CH}_{2}-\right), 4.01\left(\mathrm{~s}, \mathrm{OCH}_{3}\right), 7.10$ and 7.15 (each dd, $J=8.0$ and $1.0 \mathrm{~Hz}$, $4-\mathrm{H}$ and $6-\mathrm{H}), 7.75(\mathrm{t}, J=8.0 \mathrm{~Hz}, 5-\mathrm{H})$. Anal. Calcd. for $\mathrm{C}_{12} \mathrm{H}_{10} \mathrm{O}_{5}: \mathrm{C}, 61.54 ; \mathrm{H}, 4.30$. Found: $\mathrm{C}, 61.79$; $\mathrm{H}, 4.24$.

Methyl 4-(2'-Carbomethoxy-6'-methoxyphenyl)-4-oxobutyrate (10)_-A suspension of dilactone (6) $(475 \mathrm{mg})$ in $2 \mathrm{~N} \mathrm{NaOH}(10 \mathrm{ml})$ was stirred for $1 \mathrm{hr}$ at $60^{\circ}$. The cooled reaction mixture was acidified with $10 \%$ sulfuric acid and extracted with AcOEt $(4 \times 25 \mathrm{mI})$. The combined extracts were washed with sat. aq. $\mathrm{NaCl}$, dried over anhyd. $\mathrm{MgSO}_{4}$ and evaporated in vacuo to give a crystalline residue (502 $\mathrm{mg}$ ). After treatment of this substance with $\mathrm{CH}_{2} \mathrm{~N}_{2}$, the product $(504 \mathrm{mg}$ ) was purified by distillation to yield 10 as a colorless oil, bp $160^{\circ}$ (bath temp.)/1 mmHg. TLC: $\mathrm{C}_{6} \mathrm{H}_{6}$-ether (7:3), Rf 0.40; IR $\nu_{\text {max }}^{\mathrm{CHCl}_{3}} \mathrm{~cm}^{-1}: 1720,1590,1580$; NMR $\left(\mathrm{CDCl}_{3}\right) \delta: 2.62-2.90\left(\mathrm{~m}, 2-\mathrm{H}_{2}\right), 3.03-3.32\left(\mathrm{~m}, 3-\mathrm{H}_{2}\right), 3.70\left(\mathrm{~s}, 1-\mathrm{COOCH}_{3}\right), 3.81$ and $3.84\left(\right.$ each s, 6'- $\mathrm{OCH}_{3}$ and $2^{\prime}-\mathrm{COOCH}_{3}$ ), 7.10 (dd, $J=8.0$ and $2.0 \mathrm{~Hz}, 5^{\prime}-\mathrm{H}$ ), 7.38 (t, $J=8.0 \mathrm{~Hz}, 4^{\prime}-\mathrm{H}$ ), 7.58 (dd, $J=8.0$ and $2.0 \mathrm{~Hz}$, $\left.3^{\prime}-\mathrm{H}\right)$. Anal. Calcd. for $\mathrm{C}_{14} \mathrm{H}_{16} \mathrm{O}_{6}: \mathrm{C}, 59.99 ; \mathrm{H}, 5.75$. Found: $\mathrm{C}, 59.80 ; \mathrm{H}, 5.53$.

Methyl 4-(2'-Carbomethoxy-6'-hydroxyphenyl)-4-oxobutyrate $(11)$ - $\mathrm{A} 20 \mathrm{w} / \mathrm{v} \%$ solution $(2.8 \mathrm{ml})$ of $\mathrm{BBr}_{3}$ in anhyd. $\mathrm{CH}_{2} \mathrm{Cl}_{2}$ was added dropwise to a solution of $10(463 \mathrm{mg})$ in anhyd. $\mathrm{CH}_{2} \mathrm{Cl}_{2}(6.7 \mathrm{ml})$ at $-74^{\circ}$. After standing at the same temperature for an additional $1 \mathrm{hr}$, the reaction mixture was brought to room temperature and kept for a further $2.5 \mathrm{hr}$. The reaction mixture was cooled again to $-74^{\circ}$ and $\mathrm{H}_{2} \mathrm{O}(35 \mathrm{ml})$ was carefully added. After warming to room temperature, the $\mathrm{CH}_{2} \mathrm{Cl}_{2}$ layer was separated and the aqueous layer was extracted with $\mathrm{CHCl}_{3}(3 \times 25 \mathrm{ml})$. The combined organic extracts were washed successively with sat. aq. $\mathrm{NaHCO}_{3}$ and sat. aq. $\mathrm{NaCl}$, dried over anhyd. $\mathrm{MgSO}_{4}$ and the solvent was removed in vacuo to give a crystalline residue $(430 \mathrm{mg})$ which was recrystallized from $\mathrm{CHCl}_{3}$-pet. ether to afford 11 as colorless plates,

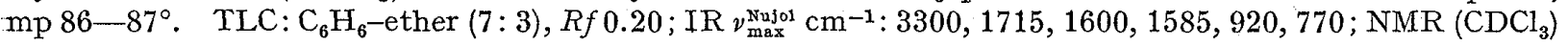

10) E. Grotzinger and I.M. Campbell, Phytochemistry, 11, 675 (1972).

11) For general procedures, see reference 1. 
$\delta: 2.68-2.95\left(\mathrm{~m}, 2-\mathrm{H}_{2}\right), 3.02-3.30\left(\mathrm{~m}, 3-\mathrm{H}_{2}\right), 3.71\left(\mathrm{~s}, 1-\mathrm{COOCH}_{3}\right), 3.87\left(\mathrm{~s}, 2^{\prime}-\mathrm{COOCH}_{3}\right), 7.00-7.45(\mathrm{~m}, 3$ aromatic protons and phenolic $\mathrm{OH}$; one proton signal disappeared upon treatment with $\mathrm{D}_{2} \mathrm{O}$ ). Anal. Calcd. for $\mathrm{C}_{13} \mathrm{H}_{14} \mathrm{O}_{6}: \mathrm{C}, 58.65 ; \mathrm{H}, 5.30$. Found: $\mathrm{C}, 58.59 ; \mathrm{H}, 5.36$.

Treatment of Methyl 4-(2'-Carbomethoxy-6'-hydroxyphenyl)-4-oxobutyrate (11) with 50\% Sulfuric Acid

A mixture of $11(60 \mathrm{mg})$ in $50 \% \mathrm{H}_{2} \mathrm{SO}_{4}(20 \mathrm{ml})$ was refluxed gently for $2 \mathrm{hr}$. The mixture was diluted with $\mathrm{H}_{2} \mathrm{O}(20 \mathrm{ml})$ and extracted with ether $(3 \times 20 \mathrm{ml})$. The combined ether extracts were washed with sat. aq. $\mathrm{NaCl}$, dried over anhyd. $\mathrm{MgSO}_{4}$ and evaporated in vacuo. The resulting crystalline residue (35 $\mathrm{mg}$ ) was methylated with $\mathrm{CH}_{2} \mathrm{~N}_{2}$. Purification of the product by preparative TLC $\left(\mathrm{C}_{6} \mathrm{H}_{6}\right.$-ether $7: 3$, Rf 0.40$)$ followed by recrystallization from $\mathrm{C}_{6} \mathrm{H}_{6}$-pet, ether yielded colorless needles, $\mathrm{mp} 69-71^{\circ}$, which was identical in mixed $\mathrm{mp}, \mathrm{IR}$ and NMR spectra with an authentic sample of methyl 3 -hydroxybenzoate (8).

Methyl 4-(2'-Carbomethoxy-3'-methoxyphenyl)-4-oxobutyrate (12)—Dilactone (7) (527 mg) was hydrolyzed with $2 \mathrm{~N} \mathrm{NaOH}(15 \mathrm{ml})$ and subsequently methylated with $\mathrm{CH}_{2} \mathrm{~N}_{2}$ to give 12 as a colorless oil, bp $140^{\circ}$ (bath temp.) $/ 0.8 \mathrm{mmHg}$. TLC: $\mathrm{C}_{6} \mathrm{H}_{6}$-ether $(7: 3)$, Rf 0.30 ; IR $\nu_{\max }^{\mathrm{CHCl}_{3}} \mathrm{~cm}^{-1}: 1730,1690,1590,790$; $\operatorname{NMR}\left(\mathrm{CDCl}_{3}\right) \delta: 2.57-2.87^{\prime}\left(\mathrm{m}, 2-\mathrm{H}_{2}\right), 3.13-3.40\left(\mathrm{~m}, 3-\mathrm{H}_{2}\right), 3.68\left(\mathrm{~s}, 1-\mathrm{COOCH}_{3}\right), 3.85\left(\mathrm{~s}, \mathrm{OCH}_{3}\right), 3.90(\mathrm{~s}$, $\left.2^{\prime}-\mathrm{COOCH}_{3}\right), 7.14\left(\mathrm{t}, J=5.0 \mathrm{~Hz}, 5^{\prime}-\mathrm{H}\right), 7.48$ and 7.49 (each d, $J=5.0 \mathrm{~Hz}, 4^{\prime}-\mathrm{H}$ and $6^{\prime}-\mathrm{H}$ ). Anal. Calcd. for $\dot{\mathrm{C}}_{14} \mathrm{H}_{16} \mathrm{O}_{6}: \mathrm{C}, 59.99 ; \mathrm{H}, 5.75$. Found: $\mathrm{C}, 59.94 ; \mathrm{H}, 5.65$.

Methyl 4-(2'-Carbomethoxy-3'-hydroxyphenyl)-4-oxobutyrate (13)—A $20 \mathrm{w} / \mathrm{v} \%$ solution (8.4 ml) of $\mathrm{BBr}_{3}$ in anhyd. $\mathrm{CH}_{2} \mathrm{Cl}_{2}$ was added dropwise to a solution of $12(1.35 \mathrm{~g})$ in anhyd. $\mathrm{CH}_{2} \mathrm{Cl}_{2}$ at $-74^{\circ}$. Work up of the mixture as described above for 11 yielded a residue $(1.13 \mathrm{~g})$ which was chromatographed on silica gel $(30 \mathrm{~g})$ with increasing percentage of ether in $\mathrm{C}_{6} \mathrm{H}_{6}$ as eluent to give $13(776 \mathrm{mg})$ as a colorless oil, bp $160^{\circ}$ (bath temp.) $/ 1 \mathrm{mmHg}$. TLC: $\mathrm{C}_{6} \mathrm{H}_{6}$-ether $(7: 3)$, Rf $0.40 ;$ IR $v_{\max }^{\mathrm{CHCl}_{3}} \mathrm{~cm}^{-1}: 3100,1730,1705,1680,1605$, 1580,$810 ; \mathrm{NMR}\left(\mathrm{CDCl}_{3}\right) \delta: 2.57-2.85\left(\mathrm{~m}, 2-\mathrm{H}_{2}\right), 2.96-3.25\left(\mathrm{~m}, 3-\mathrm{H}_{2}\right), 3.72\left(\mathrm{~s}, 1-\mathrm{COOCH}_{3}\right), 3.90\left(\mathrm{~s}, 2^{\prime}-\mathrm{COO}-\right.$ $\mathrm{CH}_{3}$ ), $6.76\left(\mathrm{dd}, J=7.0\right.$ and $1.0 \mathrm{~Hz}, 4^{\prime}-\mathrm{H}$ ), 7.05 (dd, $J=9.0$ and $1.0 \mathrm{~Hz}, 6^{\prime}-\mathrm{H}$ ), 7.48 (dd, $J=9.0$ and $7.0 \mathrm{~Hz}$, $5^{\prime}-\mathrm{H}$ ), 10.80 (broad $\mathrm{s}$, phenolic $\mathrm{OH}$, disappeared upon treatment with $\mathrm{D}_{2} \mathrm{O}$ ). Anal. Calcd. for $\mathrm{C}_{13} \mathrm{H}_{14} \mathrm{O}_{6}$ : C, 58.65; H, 5.30. Found: C, 58.41; H, 5.09.

Treatment of Methyl 4-(2'-Carbomethoxy-3'-hydroxyphenyl)-4-oxobutyrate (13) with 50\% Sulfuric Acid

$13(77 \mathrm{mg})$ was treated with $50 \% \mathrm{H}_{2} \mathrm{SO}_{4}(20 \mathrm{ml})$ and subsequently methylated with $\mathrm{CH}_{2} \mathrm{~N}_{2}$ by the same procedure as described for the preparation of 8 . The product was purified by preparative TLC $\left(\mathrm{C}_{6} \mathrm{H}_{6}-\mathrm{ether}\right.$ $7: 3, R f 0.30)$ to give a crystalline residue $(28 \mathrm{mg})$ which was recrystallized from ether-pet. ether to yield 9 as colorless leaflets, $\mathrm{mp} 104-105^{\circ}$. IR $\nu_{\max }^{\text {Nujol }} \mathrm{cm}^{-1}: 3300,1735,1708,1678,1600,880,785 ; \mathrm{NMR}\left(\mathrm{CDCl}_{3}\right)$ $\delta: 2.60-2.88\left(\mathrm{~m}, 2-\mathrm{H}_{2}\right), 3.15-3.44\left(\mathrm{~m}, 3-\mathrm{H}_{2}\right), 3.69\left(\mathrm{~s}, \mathrm{COOCH}_{3}\right), 6.50$ (broad s, phenolic OH; disappeared upon treatment with $\left.\mathrm{D}_{2} \mathrm{O}\right), 6.90-7.60$ (m, 4 aromatic protons). Anal. Calcd. for $\mathrm{C}_{11} \mathrm{H}_{12} \mathrm{O}_{4}: \mathrm{C}, 63.45 ; \mathrm{H}$, 5.81. Found: C, $63.60 ; \mathrm{H}, 5.77$.

Methyl 4-(2'-Carbomethoxy $3^{\prime}-\left(1^{\prime \prime}-\right.$ phenyl-5" -tetrazolyloxy)phenyl)-4-oxobutyrate (14)-A mixture of 13 (100 mg), 1-chloro-5-phenyltetrazole $(102 \mathrm{mg})$ and anhyd. $\mathrm{K}_{2} \mathrm{CO}_{3}(206 \mathrm{mg})$ in anhyd. acetone $(4 \mathrm{ml})$ was refluxed with stirring under $\mathrm{N}_{2}$ for $8 \mathrm{hr}$. Water $(20 \mathrm{ml})$ was added to the mixture cooled on an ice bath. The resulting mixture was adjusted to $\mathrm{pH} 2$ with $1 \mathrm{~N} \mathrm{HCl}$ and was extracted with $\mathrm{AcOEt}(3 \times 20 \mathrm{mI})$. The combined extracts were washed with sat. aq. $\mathrm{NaCl}$, dried over anhyd. $\mathrm{MgSO}_{4}$ and evaporated in vacuo to give a residue which was purified by preparative TLC $\left(\mathrm{C}_{6} \mathrm{H}_{6}\right.$-ether $\left.7: 3, R f 0.35\right)$. The crystalline product (70 mg) was recrystallized from MeOH to give 14 as colorless prisms, $\mathrm{mp} 134-135^{\circ}$. IR $\nu_{\max }^{\mathrm{Nujol}} \mathrm{cm}^{-1}: 1730,1688$, $1605,1545,1510,800,760 ; \mathrm{NMR}\left(\mathrm{CDCl}_{3}\right) \delta: 2.75\left(\mathrm{t}, J=6.5 \mathrm{~Hz}, 2-\mathrm{H}_{2}\right), 3.30\left(\mathrm{t}, J=6.5 \mathrm{~Hz}, 3-\mathrm{H}_{2}\right), 3.67$ and 3.68 (each s, $\left.2 \times \mathrm{COOCH}_{3}\right), 7.45-8.06$ (m, 8 aromatic protons). Anal. Calcd. for $\mathrm{C}_{20} \mathrm{H}_{18} \mathrm{O}_{6} \mathrm{~N}_{4}: \mathrm{C}, 58.53 ; \mathrm{H}$, $4.42 ; \mathrm{N}, 13.65$. Found: $\mathrm{C}, 58.65 ; \mathrm{H}, 4.30 ; \mathrm{N}, 13.68$.

Hydrogenolysis of Tetrazolyloxy-ether (14)__ A solution of tetrazolyloxy-ether (14) (85 $\mathrm{mg})$ in $\mathrm{MeOH}$ $\left(15 \mathrm{ml}\right.$ ) was stirred under $\mathrm{H}_{2}$ over a $10 \% \mathrm{Pd}-\mathrm{C}$ (prepared from $10 \% \mathrm{PdCl}_{2}-\mathrm{HCl}$ solution $(1.10 \mathrm{ml}$ ) and activated charcoal $(90 \mathrm{mg})$ ) at room temperature. After $14 \mathrm{hr}$, the catalyst was filtered off and washed with $\mathrm{MeOH}$. The combined filtrate and washings were evaporated in vacuo to give a crystalline residue (73 mg) which was purified by preparative TLC $\left(\mathrm{C}_{6} \mathrm{H}_{6}\right.$-ether $\left.7: 3\right)$. The crystalline residue $(30 \mathrm{mg})$ obtained from the zone around $R f 0.52$ was recrystallized from ether-pet. ether to give 15 as colorless pillars, $\operatorname{mp} 36-37^{\circ}$. IR $\nu_{\max }^{\text {Nujos }}$ $\mathrm{cm}^{-1}: 1775,1720,1615,1600,760,750 ; \mathrm{NMR}\left(\mathrm{CDCl}_{3}\right) \delta: 1.86-2.67\left(\mathrm{~m}, 1^{\prime}-\mathrm{H}_{2}\right.$ and $\left.2^{\prime}-\mathrm{H}_{2}\right), 3.68\left(\mathrm{~s}, \mathrm{COOCH}_{3}\right)$, $5.58(\mathrm{dd}, J=8.0$ and $3.0 \mathrm{~Hz}, 3-\mathrm{H}), 7.36-7.78\left(\mathrm{~m}, 4,5,6-\mathrm{H}_{3}\right), 7.81-8.01(\mathrm{~m}, 7-\mathrm{H})$. Mass Spectrum $m / e$ : $220\left(\mathrm{M}^{+}\right)$. Anal. Calcd. for $\mathrm{C}_{12} \mathrm{H}_{12} \mathrm{O}_{4}: \mathrm{C}, 65.44 ; \mathrm{H}, 5.49$. Found: $\mathrm{C}, 65.35 ; \mathrm{H}, 5.52$. A colorless oil (16) (12 mg) was obtained from the zone around $R f 0.75$. IR $\nu_{\max }^{\mathrm{CHCl}_{3}} \mathrm{~cm}^{-1}: 1720,1600 ; \mathrm{NMR}\left(\mathrm{CDCl}_{3}\right) \delta: 1.75-2.10(\mathrm{~m}$, $\left.3-\mathrm{H}_{2}\right), 2.13-2.56\left(\mathrm{dd}, J=13.0\right.$ and $\left.8.0 \mathrm{~Hz}, 2-\mathrm{H}_{2}\right), 2.87-3.18\left(\mathrm{t}, J=7.0 \mathrm{~Hz}, 4-\mathrm{H}_{2}\right), 3.66\left(\mathrm{~s}, 1-\mathrm{COOCH}_{3}\right), 3.88$ $\left(\mathrm{s}, 2^{\prime}-\mathrm{COOCH}_{3}\right), 7.07-7.50\left(\mathrm{~m}, 4^{\prime}, 5^{\prime}, 6^{\prime}-\mathrm{H}_{3}\right), 7.77-8.00\left(\mathrm{~m}, 3^{\prime}-\mathrm{H}\right)$. Mol. wt. Calcd. for $\mathrm{C}_{13} \mathrm{H}_{16} \mathrm{O}_{4}: 236.105$. Found: 236.105 .

Methyl 4-(2'-Carbomethoxyphenyl)-4-oxobutyrate (17)—A mixture of phthalide (15) (100 mg) and $\mathrm{N}$-bromosuccinimide $(70 \mathrm{mg})$ in anhyd. $\mathrm{CCl}_{4}(2 \mathrm{ml})$ was irradiated with a UV lamp under $\mathrm{N}_{2}$ for $30 \mathrm{~min}$ while it was stirred and warmed with an IR lamp. The precipitate was filtered off and washed with $\mathrm{CCl}_{4}$. The combined filtrate and washings were evaporated in vacuo and the residue $(104 \mathrm{mg})$ was stirred with $1 \mathrm{~N}$ $\mathrm{HCl}(8 \mathrm{ml})$ for $30 \mathrm{~min}$. The reaction mixture was extracted with AcOEt $(4 \times 20 \mathrm{ml})$.. The combined AcOEt extracts were washed with sat. aq. $\mathrm{NaCl}$, dried over anhyd. $\mathrm{MgSO}_{4}$ and evaporated in vacuo. The crude product was methylated with $\mathrm{CH}_{2} \mathrm{~N}_{2}$ and purified by preparative TLC $\left(\mathrm{C}_{6} \mathrm{H}_{6}\right.$-ether, Rf 0.58$)$ to give 17 (65 mg) 
as an oil, bp $145^{\circ}$ (bath temp.) $/ 1 \mathrm{mmHg}$. IR $\nu_{\max }^{\mathrm{CHCl}_{3}} \mathrm{~cm}^{-1}: 1725,1598,1575,800 ; \mathrm{NMR} \delta: 2.62-2.93$ (m, $\left.2-\mathrm{H}_{2}\right), 3.05-3.30\left(\mathrm{~m}, 3-\mathrm{H}_{2}\right), 3.70\left(\mathrm{~s}, 1-\mathrm{COOCH}_{3}\right), 3.87\left(\mathrm{~s}, 2^{\prime}-\mathrm{COOCH}_{3}\right), 7.35-8.01$ ( $\mathrm{m}, 4$ aromatic protons); Mass Spectrum m/e: $250\left(\mathrm{M}^{+}\right)$. Anal. Calcd. for $\mathrm{C}_{13} \mathrm{H}_{14} \mathrm{O}_{5}: \mathrm{C}, 62.40 ; \mathrm{H}, 5.64$. Found: $\mathrm{C}, 62.31 ; \mathrm{H}, 5.79$.

Hydrogenolysis of Tetrazolyloxy-ether (14) with Deuterium-A solution of 14 (200 mg) in $\mathrm{MeOH}$ $(30 \mathrm{ml})$ was stirred under deuterium over $10 \% \mathrm{Pd}-\mathrm{C}$ (prepared from $10 \% \mathrm{PdCl}_{2}-\mathrm{HCl}(1.10 \mathrm{ml})$ and activated charcoal $(90 \mathrm{mg})$ under deuterium) at room temperature. Work up in the same manner as described above gave $15-\mathrm{d}_{2}(33 \mathrm{mg})$ as colorless crystals and $16-\mathrm{d}_{3}(25 \mathrm{mg})$ as a colorless oil. Mass Spectra: 15- $\mathrm{d}_{2}, m / e$ 222 $\left(\mathrm{M}^{+}\right) ; 16-\mathrm{d}_{3}, m / e 239\left(\mathrm{M}^{+}\right)$.

Methyl [3'-2H]-4-(2'-Carbomethoxyphenyl)-4-oxobutyrate $\left(17-\mathrm{d}_{1}\right)$-Treatment of $15-\mathrm{d}_{2}(29 \mathrm{mg})$ in the same way as described for the conversion of 15 to 17 gave $17-d_{1}(18 \mathrm{mg})$ as a colorless oil, which showed the same $R f$ as that of 17. Mass Spectrum m/e: $251\left(\mathrm{M}^{+}\right)$.

3-(2'-Carbomethoxyethyl)-phthalide (15)- $-\mathrm{NaBH}_{4}(38 \mathrm{mg})$ was added to an ice-cooled solution of 17 $(220 \mathrm{mg})$ in $\mathrm{MeOH}(3 \mathrm{ml})$ with stirring and the mixture was stirred at room temperature for an additional hour, diluted with $\mathrm{H}_{2} \mathrm{O}(30 \mathrm{ml})$, adjusted to $\mathrm{pH} 4.0$ with $1 \mathrm{~N} \mathrm{HCl}$ and extracted with $\mathrm{CHCl}_{3}(3 \times 15 \mathrm{ml})$. The combined $\mathrm{CHCl}_{3}$ extracts were washed with sat. aq. $\mathrm{NaCl}$, dried over anhyd. $\mathrm{MgSO}_{4}$ and evaporated in vacuo. The crystalline residue $(215 \mathrm{mg})$ was recrystallized from ether-pet. ether to yield colorless pillars, $\mathrm{mp} 36-37^{\circ}$, which were identified with 15 obtained by hydrogenolysis of 14 by mixed $\mathrm{mp}$ and IR comparison.

Dieckmann Condensation of 3-(2'-Carbomethoxyethyl)-phthalide (15)-A solution of phthalide (15) $(180 \mathrm{mg})$ in anhyd. toluene $(1 \mathrm{ml})$ was added dropwise to a suspension of potassium $t$-butoxide $(300 \mathrm{mg})$ in anhyd. toluene $\left(3 \mathrm{ml}\right.$ ) at $110-115^{\circ}$ (bath temp.) under $\mathrm{N}_{2}$ over a period of 45 min and the resulting mixture was heated under gentle reflux for an additional hour. The ice-cooled reaction mixture was diluted with $\mathrm{H}_{2} \mathrm{O}(20 \mathrm{ml})$, adjusted to $\mathrm{pH} 2$ with $1 \mathrm{~N} \mathrm{HCl}$ and extracted with ether $(3 \times 20 \mathrm{ml})$. The extracts were washed with sat. aq. $\mathrm{NaCl}$, dried over anhyd. $\mathrm{MgSO}_{4}$ and concentrated to $20 \mathrm{ml}$, to which excess $\mathrm{CH}_{2} \mathrm{~N}_{2}-$ ether was added and immediately evaporated in vacuo. The oily residue $(158 \mathrm{mg})$ was purified by preparative TLC $\left(\mathrm{C}_{6} \mathrm{H}_{6}\right.$-ether $\left.7: 3\right)$. The crystalline residue $(15.0 \mathrm{mg})$ obtained from the zone around $R f 0.64$ was recrystallized from EtOH to give 20 as colorless needles, mp 77-78. IR $\nu_{\max }^{\mathrm{CHCl}_{3}} \mathrm{~cm}^{-1}: 3050,1660,1635,1600,1580 ; \mathrm{NMR}$ $\left(\mathrm{CDCl}_{3}\right) \delta: 3.90\left(\mathrm{~s}, \mathrm{COOCH}_{3}\right), 7.13-7.80\left(\mathrm{~m}, 3,4,5,6,7-\mathrm{H}_{5}\right), 8.30-8.50(\mathrm{~m}, 8-\mathrm{H}), 11.98(\mathrm{~s}$, phenolic OH, disappeared upon treatment with $\left.\mathrm{D}_{2} \mathrm{O}\right)$. Anal. Calcd. for $\mathrm{C}_{12} \mathrm{H}_{10} \mathrm{O}_{3}: \mathrm{C}, 71.28 ; \mathrm{H}, 4.98$. Found: $\mathrm{C}, 71.23 ; \mathrm{H}$, 5.19. The crystalline residue $(120 \mathrm{mg})$ obtained from the zone around $R f 0.28$ was recrystallized from $\mathrm{C}_{6} \mathrm{H}_{6}-$ $n$-hexane to give 19 as colorless needles, $\operatorname{mp} 67-68^{\circ}$. IR $v_{\max }^{\text {Nujol }} \mathrm{cm}^{-1}: 3300-3200,1755$ (sh.), 1735,1715 (sh.), 1670 (sh.), 1642, 1615, 1590, 1560; IR $\nu_{\max }^{\mathrm{CHCl}_{3}} \mathrm{~cm}^{-1}$ : 3600-3400, 1730, 1715 (sh.), 1680, 1640, 1610, 1595, 1560; NMR $\left(\mathrm{CDCl}_{3}\right) \delta: 2.35$ (broad s, 4-OH, disappeared upon treatment with $\left.\mathrm{D}_{2} \mathrm{O}\right), 2.80\left(\mathrm{~d}, J=6.0 \mathrm{~Hz}_{2}, 3-\mathrm{H}_{3}\right), 3.82$ ( $\left.\mathrm{s}, \mathrm{COOCH}_{3}\right), 4.81$ ( $\left.\mathrm{t}, J=6.0 \mathrm{~Hz}, 4-\mathrm{H}\right), 7.38-8.10$ (m, 4 aromatic protons), 12.43 (s, 1-OH, disappeared upon treatment with $\left.\mathrm{D}_{2} \mathrm{O}\right)$. Anal. Calcd. for $\mathrm{C}_{12} \mathrm{H}_{12} \mathrm{O}_{4}: \mathrm{C}, 65.45 ; \mathrm{H}, 5.49$. Found: C, 65.53; $\mathrm{H}, 5.70$. From the zone around $R f 0.15,21$ was obtained as a colorless oil $(7 \mathrm{mg})$. IR $v_{\max }^{\mathrm{CHCl}_{3}} \mathrm{~cm}^{-1}: 3400,1680,1600$, 930; NMR $\left(\mathrm{CDCl}_{3}\right) \delta: 1.97-2.45\left(\mathrm{~m}, 3-\mathrm{H}_{2}\right), 2.50-3.04\left(\mathrm{~m}, 2-\mathrm{H}_{2}\right), 2.90$ (broad, s, 4-OH, disappeared upon treatment with $\left.\mathrm{D}_{2} \mathrm{O}\right), 4.93$ (dd, $J=4.5$ and $\left.7.0 \mathrm{~Hz}, 4-\mathrm{H}\right), 7.16-7.66\left(\mathrm{~m}, 5,6,7-\mathrm{H}_{3}\right), 7.87-8.09(\mathrm{~m}, 8-\mathrm{H})$.

2-Carboxy-4-hydroxy- $\alpha$-tetralone (CHT) — A mixture of CHT methyl ester (19) (96 mg) in $0.5 \mathrm{~N} \mathrm{NaOH}$ $(4 \mathrm{ml})$ was stirred at room temperature for $2 \mathrm{hr}$. The ice-cooled reaction mixture was adjusted to $\mathrm{pH} 2$ with $1 \mathrm{~N} \mathrm{HCl}$ and extracted with ether $(4 \times 7 \mathrm{ml})$. The combined ether extracts were washed with sat. aq. $\mathrm{NaCl}$, dried over anhyd. $\mathrm{MgSO}_{4}$ and evaporated in vacuo to give a crystalline residue (82 $\mathrm{mg}$ ) which was

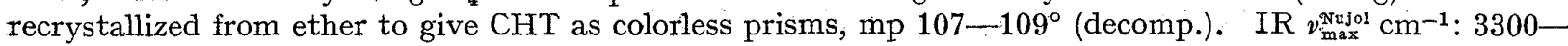
$3200,2700-2300,1640,1605,1585,1560 ;$ NMR (acetone- $d_{6}$ ) $\delta: 2.73$ (dd, $J=15.5$ and $9.0 \mathrm{~Hz}_{z}, 3-\mathrm{H}_{2 \mathrm{x}}$ ), 2.83 (dd, $J=15.5$ and $6.0 \mathrm{~Hz}, 3-\mathrm{H}_{\mathrm{eq}}$ ), 4.87 (dd, $J=9.0$ and $6.0 \mathrm{~Hz}, 4-\mathrm{H}$ ), 5.50-7.30 (broad s, 4-OH and COOH, disappeared on addition of $\mathrm{D}_{2} \mathrm{O}$ ), $7.25-8.10(\mathrm{~m}, 4$ aromatic protons), 13.0 (broad $\mathrm{s}, 1-\mathrm{OH}$, disappeared on addition of $\mathrm{D}_{2} \mathrm{O}$ ). An ice-cooled methanolic solution of $\mathrm{CHT}$ thus obtained was mixed with $\mathrm{CH}_{2} \mathrm{~N}_{2}$-ether and the mixture was immediately concentrated to give CHT methyl ester (19).

Oxidation of CHT Methyl Ester (19) with $\mathrm{MnO}_{2}$ - Activated $\mathrm{MnO}_{2}(200 \mathrm{mg}$, prepared acc. to the method of Attenburrow, et al. $\left.{ }^{12)}\right)$ was added to a stirred solution of $19(50 \mathrm{mg})$ in $\mathrm{CHCl}_{3}(3 \mathrm{ml})$ and stirring was continued at room temperature for $15 \mathrm{hr}$. The precipitate was filtered off and washed with hot $\mathrm{CHCl}_{3}$. The filtrate and washings were combined and evaporated in vacuo to give a residue which was purified by preparative TLC $\left(\mathrm{CHCl}_{3}, R f 0.40\right)$. Recrystallization of the crystalline product $(25 \mathrm{mg})$ from ether-pet. ether to afford 23 as colorless needles, $\operatorname{mp} 95-98^{\circ}$. IR $v_{\max }^{\mathrm{CrCl}_{3}} \mathrm{~cm}^{-1}: 3500,1740,1695,1595,955,930 ; \mathrm{NMR}\left(\mathrm{CDCl}_{3}\right) \delta: 3.11$ and 3.65 (each d, $\left.J=17.0 \mathrm{~Hz}, 3-\mathrm{H}_{2}\right), 3.70\left(\mathrm{~s}, \mathrm{COOCH}_{3}\right), 4.55$ (broad s, 2-OH, disappeared on addition of $\mathrm{D}_{2} \mathrm{O}$ ), $7.70-7.95\left(\mathrm{~m}, 6,7-\mathrm{H}_{2}\right), 7.95-8.23\left(\mathrm{~m}, 5,8-\mathrm{H}_{2}\right)$. Mol wt. Calcd. for $\mathrm{C}_{12} \mathrm{H}_{10} \mathrm{O}_{5}: 234.053$. Found: 234.049 .

Alkali Treatment of 2-Hydroxy-CHT Methyl Ester (23)_-A mixture of $23(20 \mathrm{mg})$ in $1 \mathrm{~N} \mathrm{NaOH}(1 \mathrm{ml})$ was stirred at room temperature for $2 \mathrm{hr}$. The resulting solution was adjusted to $\mathrm{pH} 2$ with $1 \mathrm{~N} \mathrm{HCl}$ and extracted with AcOEt $(3 \times 5 \mathrm{ml})$. The combined AcOEt extracts were washed with sat. aq. $\mathrm{NaCl}$, dried over anhyd. $\mathrm{MgSO}_{4}$ and evaporated in vacuo. The yellow crystalline residue $(14.4 \mathrm{mg})$ was recrystallized

12) J. Attenburrow, A.F.B. Cameron, J.H. Chapman, R.M. Evans, B.A. Hems, A.B.A. Jamsen, and T. Walker, J. Chem. Soc., 1952, 1094. 
from acetic acid to give yellow needles, $\mathrm{mp} 193-195^{\circ}$, which were identified with an authentic sample of lawsone (24) by mixed $\mathrm{mp}$ and comparisons of IR and NMR spectra.

[3-2H]-3-(2'-Carbomethoxyethyl)-phthalide $\left(15-\mathrm{d}_{1}\right)$-Reduction of $17(250 \mathrm{mg})$ with $\mathrm{NaBD}_{4}$ in the same manner as described above for the conversion of 17 to 15 gave $15-\mathrm{d}_{1}$ as crystals (215 mg), the NMR spectrum of which was identical with that of 15 except for the absence of a signal at $\delta 5.58$ assignable to a. proton on $\mathrm{C}-3$ of 15 . Mass Spectrum m/e: $221\left(\mathrm{M}^{+}\right)$.

[4-2H]-2-Carbomethoxy-4-hydroxy- $\alpha$-tetralone (19-d $\left.\mathrm{d}_{1}\right)$ _Dieckmann condensation of $15-\mathrm{d}_{1}(120 \mathrm{mg})$ was carried out using the same procedure as described for the preparation of 19 . The crude product (108 mg) was purified by preparative TLC $\left(\mathrm{C}_{6} \mathrm{H}_{6}\right.$-ether $\left.7: 3\right)$. From the zone corresponding to that of 19, 19- $\mathrm{d}_{1}(35 \mathrm{mg})$ : was obtained as crystals.

[4-2H]-2-Carboxy-4-hydroxy- $\alpha$-tetralone $\left(\right.$ CHT- $\left.\mathrm{d}_{1}\right)$-Hydrolysis of CHT- $\mathrm{d}_{1}$ methyl ester $\left(19-\mathrm{d}_{1}\right)$ in the same manner as described for 19 gave CHT- $\mathrm{d}_{3}(20 \mathrm{mg})$ as colorless prisms. The NMR spectrum of this substance showed the deuteration of $40 \%$ of the proton on $\mathrm{C}-4$.

Acknowledgement This work was supported in part by a Grant-in-Aid for Scientific Research from the Ministry of Education, Science and Culture to which the authors express their gratitude. Thanks are also due to the members of the Microanalytical Center of this University for elemental analyses, to Dr. A. Kato and Mrs. M. Uobe of this Faculty for measurements of MS and NMR spectra, and to Mrs. J. Tanaka. of the Institute for Chemical Research of this University for determinations of high resolution mass spectra.

\title{
Selective Reduction of Conjugated Enones and Dienones with Trialkylsilane and Titanium Tetrachloride
}

\author{
Eirchi Yoshi, Toru Kolzumi, Ichiniro Hayashi, and Yasuko Hiror \\ Faculty of Pharmaceutical Sciences, University of Toyama1) \\ (Received October 2, 1976)
}

\begin{abstract}
The reaction of conjugated enones and dienones with trimethyl- or triethyl-silane in the presence of titanium tetrachloride followed aqueous workup produced the corresponding $\alpha, \beta$-saturated ketones. This particular Lewis acid catalysis has advantage over $\mathrm{Rh}(\mathrm{I})$ complex catalysis which fails for sterically hindered substrates.
\end{abstract}

Keywords_-hydrogenation enone; hydrogenation dienone; hydrosilylation titanium catalyst; hydrosilylation trialkylsilane; silane trialkyl

Catalytic hydrosilylation of $\alpha, \beta$-unsaturated carbonyl compounds has been employed as a synthetic tool for obtaining silyl enol ethers ${ }^{2}$ (or ketene alkyl silyl acetals ${ }^{3}$ ) ) or saturated carbonyl compounds which are readily formed on hydrolytic workup. ${ }^{3 a, 4)}$ Among a variety of catalysts, ${ }^{5)}$ classical Speier catalyst (chloroplatinic acid in isopropanol) ${ }^{6}$ ) and tris(triphenyl-

1) Location: Gofuku, Toyama 930, Japan.

2) a) A.D. Petrov and S.I. Sadykh-Zade, Doklady Akad. Nauk SSSR, 121, 119 (1958) [Chem. Abstr., 53, 1207 (1959)]; b) I. Ojima, M. Nihonyanagi, T. Kogure, M. Kumagai, S. Horiuchi, K. Nakatsugawa, and Y. Nagai, J. Organometal. Chem., 94, $449(1975) ; \quad$ ) G. Stork and T.L. Macdonald, J. Am. Chem. Soc., 97, $1264(1975)$.

3) a) E. Yoshii, Y. Kobayashi, T. Koizumi, and T. Oribe, Chem. Pharm. Bull. (Tokyo), 22, 2767 (1974); E. Yoshii, T. Koizumi, and T. Kawazoe, ibid., 24, 1957 (1976); b) A.D. Petrov, S.I. Sadykh-Zade, and E.I. Filatova, J. Gen. Chem. USSR, 29, 2896 (1959) [Chem. Abstr., 54, 11984 (1960)].

4) a) I. Ojima and T. Kogure, Tetrahedron Letters, 1972, 5035; b) E. Yoshii, T. Koizumi, H. Ikeshima, K. Ozaki, and I. Hayashi, Chem. Pharm. Bull. (Tokyo), 23, 2496 (1975).

5) C. Eaborn, "Organometallic Compounds of the Group IV Elements," Vol. I, Part 1, ed. by A.G. MacDiarmid, Marcel Dekker, Inc., New York, 1968.

6) J.L. Speier, J.A. Webster, and G.H. Barnes, J. Am. Chem. Soc., 79, 974 (1957). 